DOI: $10.37190 /$ epe 170211

\author{
ANNA WÓJCIKOWSKA-KAPUSTA ${ }^{1}$, DANUTA URBAN ${ }^{1}$, STANISŁAW BARAN ${ }^{1}$, \\ MARTA BIK-MAŁODZIŃSKA ${ }^{1}$, GRAŻYNA ŻUKOWSKA ${ }^{1}$, \\ ARTUR PAWŁOWSKI ${ }^{2}$, ANETA CZECHOWSKA-KOSACKA ${ }^{2}$
}

\title{
EVALUATION OF THE INFLUENCE OF COMPOSTS MADE OF SEWAGE SLUDGE, ASH FROM POWER PLANT, AND SAWDUST ON FLORISTIC COMPOSITION OF PLANT COMMUNITIES IN THE PLOT EXPERIMENT
}

\begin{abstract}
Floristic studies were conducted in 2011 and 2012 on the soil reclaimed using composts made of sewage sludge with the addition of various amounts of ash from power plant and sawdust. The experiment was carried out in 2002 on devastated soilless formation in the area of "Jeziórko" sulfur mine. Strongly acidic soilless formation (weak loamy sand) was reclaimed using post-flotation lime for deacidification at the dose of $300 \mathrm{t} / \mathrm{ha}$ and compost in various variants: municipal sewage sludge, sewage sludge $(80 \%)+$ ash $(20 \%)$, sewage sludge $(70 \%)+$ ash $(30 \%)$, and sewage sludge $(70 \%)+$ sawdust $(30 \%)$. The compost was added at following doses of dry weight: 90,180 , and $270 \mathrm{t} / \mathrm{ha}$. In the prepared plots, each with the area of $15 \mathrm{~m}^{2}$, a mixture of reclamation grasses was sown: Festuca pratensis - 41.2\%, Festuca rubra - 19.2\%, Lolium perenne - 14.7\%, Lolium multiflorum-12.4\%, Dactylis glomerata $-6.5 \%$, Trifolium pratense $-6 \%$. The phyto-indication method was used to evaluate the impact of different ways of the soilless formation remediation on the habitat development. The assessment took into account following indicators: soil moisture, trophism, $\mathrm{pH}$, organic matter content, resistance to salinity, and increased content of heavy metals. The largest number of species was found on plots where compost made of sewage sludge was used, while the smallest - on those reclaimed with sewage sludge compost with sawdust addition. In terms of habitat conditions, species preferring wet habitats typical of fresh soils, trophism of the subsoil corresponding to the abundant soils (eutrophic), neutral soil reaction, and subsoil with organic matter like in humus and mineral soils, dominated. The most favorable habitat conditions were found in plots reclaimed using sewage sludge compost.
\end{abstract}

${ }^{1}$ Institute of Soil Science, Environment Engineering and Management, University of Life Sciences in Lublin, ul. Leszczyńskiego 7, 20-069 Lublin, Poland, corresponding author A. Wójcikowska-Kapusta, e-mail address: anna.kapusta@up.lublin.pl

${ }^{2}$ Faculty of Environmental Engineering, Lublin University of Technology, ul. Nadbystrzycka 40B, 20-618 Lublin, Poland. 


\section{INTRODUCTION}

Development of vegetation cover on the surface of casts, sites of fire, various dumps, including industrial ones, as well as degraded areas around industrial plants is subject to specific habitat conditions, mainly pertaining to soil and moisture. Plants that spontaneously appear in such habitats are possibly characterized by low sensitivity to the adverse conditions. The impact of local vegetation (present in the adjacent areas) on phytocoenosis emerging on transformed areas devoid of vegetation is also noticeable. During assessment of the environment status, besides physicochemical methods, the phytoremediation methods are also applied. Numerous plant species are good indicators of habitat conditions. Years of detailed research have led to characterizing many plant species for specific habitat factors that are expressed in the form of ecological indices. The post-industrial areas in various parts of the country have been the subject of numerous floristic and phytosociological studies [1-7].

Sulfur extraction technology in the "Jeziórko" sulfur mine was based on a method involving the underground melting using water at the temperature above $140{ }^{\circ} \mathrm{C}$ and pumping to surface by means of an air-lift. This method entailed multiple transformations within environment, which greatly hampered the remediation of the area. Reclamation requires the improvement of soil properties. Numerous substances can be used for this purpose and the choice depends on the desired effect of their introduction to the soil, the type of damage, and availability.

The addition of sewage sludge enriched soil and provided necessary elements for plants in amounts similar to those which are introduced in the manure (except potassium). The composting process enables modifying the properties of the sewage sludge, including the addition of structural materials. The composting method is a way for recycling and economic use of municipal waste. Compost made of selected and mixed wastes constitutes a fertilizer which is usually characterized by large amounts of nitrogen, phosphorus, and potassium, while its heavy metals content does not exceed the limit values. The use of compost, as well as sewage sludge, causes a prominent increase in the organic carbon content and the sum of cations in the soil, regardless of the dose and type of compost. The method proposed aims to meet criteria of sustainable development $[8,9]$.

The present study aimed at characterizing the flora occurring on the soil reclaimed with post-flotation lime as well as composts made of municipal sewage sludge with addition of ash from power plants and sawdust, within the area of "Jeziórko" sulfur mine. Habitat conditions were evaluated by means of the phyto-indication method.

\section{MATERIALS AND METHODS}

The experiments involving plots with composts were established on 30th April 2002 on the area of the former sulfur mine "Jeziórko". The soil had a granulometric compo- 
sition of strongly acidic weak loamy sand. In order to de-acidify the soil, the post-flotation lime at a dose of $300 \mathrm{t} / \mathrm{ha}$ was applied. Municipal sewage sludge from the wastewater treatment plant in Stalowa Wola and fly ash derived from burning coal in CHP (Combined Heat and Power Station) "Stalowa Wola" were composted for six months. For field plots of an area of $15 \mathrm{~m}^{2}$ compost was added in dry weight doses: 90, 180 , and $270 \mathrm{t} / \mathrm{ha}$. Following variants were set: control (only lime), compost made of municipal sewage sludge, compost made of sewage sludge (80\%) + ash (20\%), compost made of sewage sludge $(70 \%)+$ ash $(30 \%)$, compost made of sewage sludge $(70 \%)$ $+\operatorname{ash}(30 \%)$.

Composts were mixed with a layer of soil to the depth of $25 \mathrm{~cm}$ and then a blend of reclamation grasses of the following composition was sown: meadow fescue (Festuca pratensis) $-41.2 \%$, red fescue (Festuca rubra) - 19.2\%, red clover (Trifolium pratense) - $6 \%$, Italian ryegrass (Lolium multiflorum) - 12.4\%, perennial ryegrass (Lolium perenne) $-14.7 \%$, orchard grass (Dactylis glomerata) $-6.5 \%$.

In 2011 and 2012, total of 32 phytosociological records by means of the Braun-Blanquet method [10] were taken on the experimental plots. The taxonomic affinity of species (class, order, association) was based after Matuszkiewicz [11]. Names of vascular plant species were given according to Mirek et al. [12]. Habitat conditions of plants were determined using the indicator numbers set by Zarzycki et al. [13]. The following indicators were used: $W$ - soil (water) moisture value $(1$ - very dry, 2 - dry, 3 - fresh, 4 - moist, 5 - wet, 6 - aquatic); $T r$ - trophy value ( 1 - extremely poor, 2 - poor, 3 - moderately poor, 4 - rich,

5 - very rich); $R$ - soil acidity ( $\mathrm{pH})$ value ( 1 - highly acidic, 2 - acidic, 3 -moderately acidic, 4 - neutral, 5 - alkaline); $H$ - organic matter content value $(1$ - soils poor in humus, 2 - mineral-humic soils, 3 - soils rich in organic matter); $S$ - value of resistance to $\mathrm{NaCl}$ in spoil or water $(1-$ species tolerating increased $\mathrm{NaCl}$ content (facultative halophyte), 2 - species growing mainly on soils with increased $\mathrm{NaCl}$ content (obligatory halophyte)); $M$ - value of resistance to increased heavy metal contents in the soil $(1-$ species tolerating increased heavy metal content, 2 - species requiring increased heavy metal content).

Soil samples were subject to the following determinations:

- acidity - potentiometry in $\mathrm{H}_{2} \mathrm{O}$ and $1 \mathrm{M} \mathrm{KCl}$,

- hydrolytic acidity $\left(H_{h}\right)$ - the Kappen method using $1 \mathrm{M} \mathrm{CH}_{3} \mathrm{COONa}$,

- alkaline cations $(S)$ in extract of $0.5 \mathrm{M}$ ammonia chloride (pH 8.2),

- CEC - the sum of hydrolytic acidity and alkaline cations,

- organic carbon content - the Tiurin method with Simakov modification.

\section{RESULTS}

In the upper layer $(0-20 \mathrm{~cm})$ of reclaimed soil, $\mathrm{pH}$ measured in $1 \mathrm{M} \mathrm{KCl}$ solution) was in the range 6.2-7.2 (Table 1). The content of organic carbon in reclaimed for- 
mation has increased significantly in relation to the devastated soil $(5.34 \mathrm{~g} / \mathrm{kg})$, especially in objects where the mixture of compost from sewage sludge with ash and sawdust was added $(6.59-13.44 \mathrm{~g} / \mathrm{kg})$. In the analyzed period, addition of composts has little impact of the sorption capacity $(151.1-153.3 \mathrm{mmol}(+) / \mathrm{kg})$. The highest value of sorption capacity was found in the surface layer of a soil with the addition of compost sludge. The degree of saturation of the sorption complex by basic cations was high, ranging from 86.5 to $89.5 \%$

Table 1

Basic properties of reclaimed soil in 2011-2012 (average values)

\begin{tabular}{|l|c|c|c|}
\hline \multicolumn{1}{|c|}{ Reclamation variants } & $\begin{array}{c}\mathrm{pH} \\
1 \mathrm{M} \mathrm{KCl}\end{array}$ & $\begin{array}{c}\mathrm{C} \text { org } \\
{[\mathrm{g} / \mathrm{kg}]}\end{array}$ & $\begin{array}{c}\mathrm{CEC} \\
\mathrm{mmol}(+) / \mathrm{kg}\end{array}$ \\
\hline Post-flotation lime (control) & $6.6-7.2$ & 5.34 & 152.1 \\
\hline Compost: sewage sludge $100 \%$ & $6.5-7.0$ & 6.59 & 153.3 \\
\hline Compost: sewage sludge + ash $20 \%$ & $6.5-7.0$ & 8.22 & 151.1 \\
\hline Compost: sewage sludge + ash 30\% & $6.2-7.1$ & 13.44 & 152.7 \\
\hline Compost: sewage sludge + sawdust 30\% & $6.6-7.2$ & 12.71 & 151.5 \\
\hline
\end{tabular}

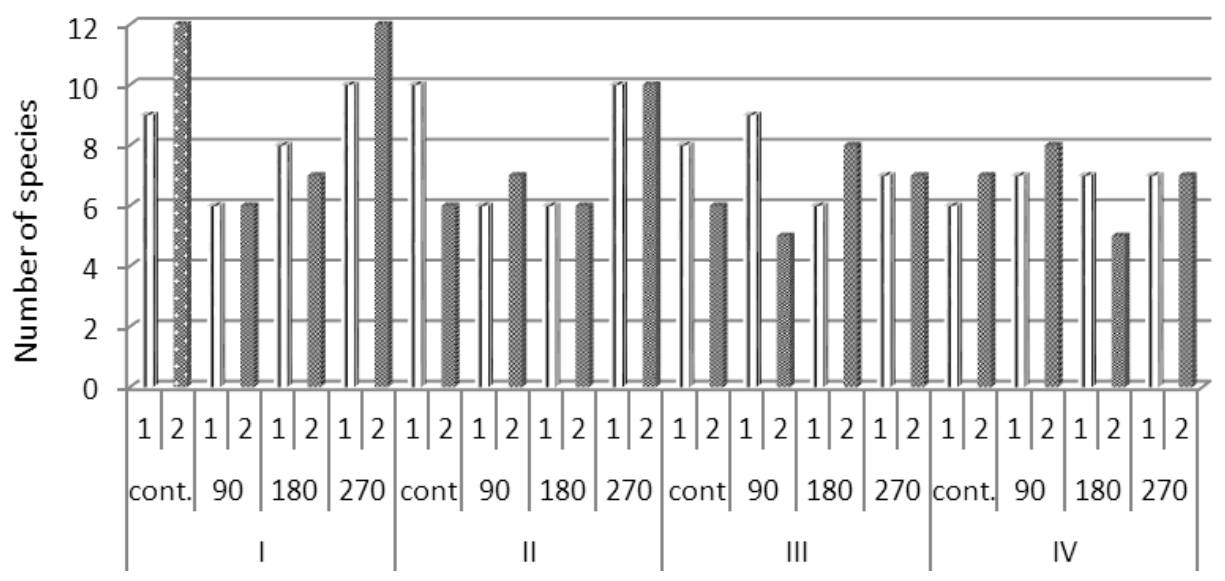

Fig. 1. Number of species of vascular plants in the studied plots: $1-2011,2-2012,90,180,270$

- dry weight dose of compost in t/ha, I - compost: sewage sludge $100 \%$, II - compost: sewage sludge and ash $20 \%$, III - compost: sewage sludge and ash $30 \%$, IV - compost: sewage sludge and sawdust $30 \%$

In the considered experiment, flora was represented by species belonging to 9 families. The most numerous species included Asteraceae (10 species), Poaceae (5 species), and Fabaceae family (three species). In other families (Plantaginaceae, Polygonaceae, Onagraceae, Geraniaceae, Caryophyllaceae, and Clusiaceae), number of species was significantly lower (one or two species). Twenty two vascular plants species grew in 2011, while in the following year, 27 species were recorded. Among them, besides the 
species sown during the remediation treatments, such as Festuca rubra, Dactylis glomerata, Trifolium pratense, there were also species that entered the process of spontaneous succession. Vegetation appeared in the experimental plots is a reflection of the flora which is located nearby (meadows, fields, roads).

The results presented in Fig. 1 indicate that the reclamation variant and study year did not have a uniform impact on the plant species present. The greatest number of species characterized the plots to which compost made of sewage sludge was applied, while the smallest - those reclaimed with compost made of sludge containing sawdust addition. The largest number of vascular plants was recorded on plots reclaimed with compost made of sewage sludge at the dose of $270 \mathrm{t} / \mathrm{ha}$.

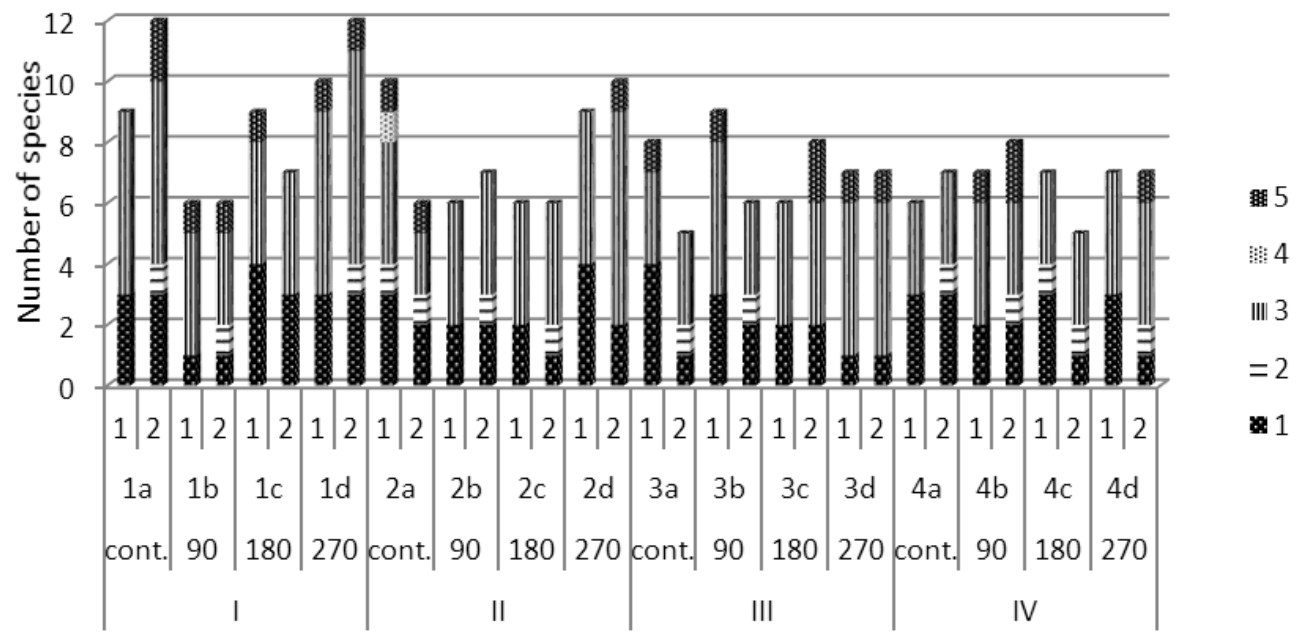

Fig. 2. Contribution of species from environmental groups in the sward of reclaimed land:

1 - meadow species, 2 - rush species, 3 - synantropic species, 4 - grassland species, 5 - other species, $1-2011,2-2012,90,180,270$ - dry weight dose of compost in t/ha, 1a-4a control plots (no additions), $1 \mathrm{~b}-4 \mathrm{~b}$ plots with compost dose of $90 \mathrm{t} / \mathrm{ha}, 1 \mathrm{c}-4 \mathrm{c}$ plots with compost dose of $180 \mathrm{t} / \mathrm{ha}, 1 \mathrm{~d}-4 \mathrm{~d}$ plots with compost dose of $270 \mathrm{t} / \mathrm{ha}$, I - compost: sewage sludge $100 \%$, II - compost: sewage sludge and ash $20 \%$,

III - compost: sewage sludge and ash $30 \%$, IV - compost: sewage sludge and sawdust $30 \%$

The presence of species from seven phytosociological classes was found on the plots of the experiment (Fig. 2). The most numerous were meadow species belonging to the class of Molinio-Arrhenatheretea - 10 species (Festuca rubra, Dactylis glomerata, Achilleea millefolium, Poa pratensis, Plantago lanceolata, Trifolium pratense, $R u$ mex acetosa, Taraxacum officinale, Daucus carota, Plantago major) and from synanthropic class of Artemisietea vulgaris (Solidago canadensis, Cirsium arvense, Epilobium parviflorum, Oenothera biennis, Melandrium album, Artemisia vulgaris, Tanacetum vulgare), Stellarietea mediae (Vicci tetrasperma), Epilobietea angustifolii (Calamagrostis epigejos), and Polygono-Chenopodietea (Sonchus arvensis) - a total of 12 species. Considering other classes, reed species of Phragmitetea class (one species 
- Phragmites australis), as well as the sand grasses of Koelerio glaucae - Corynephoretum canescentis class (only in a single phytosociological record - Rumex acetosella), prevailed. The accompanying species, included: Artemisia annua, Erigeron acris, Erodium cicutarium, and Hypericum perforatum.

In both years, the presence of Calamagrostis epigejos was recorded in all plots, regardless of the reclamation variant (Fig. 3). Festuca rubra, Dactylis glomerata, as well as Epilobium parviflorum and Solidago canadensis were also found very often. The study shows that Phragmites australis was present in almost all plots in 2012.

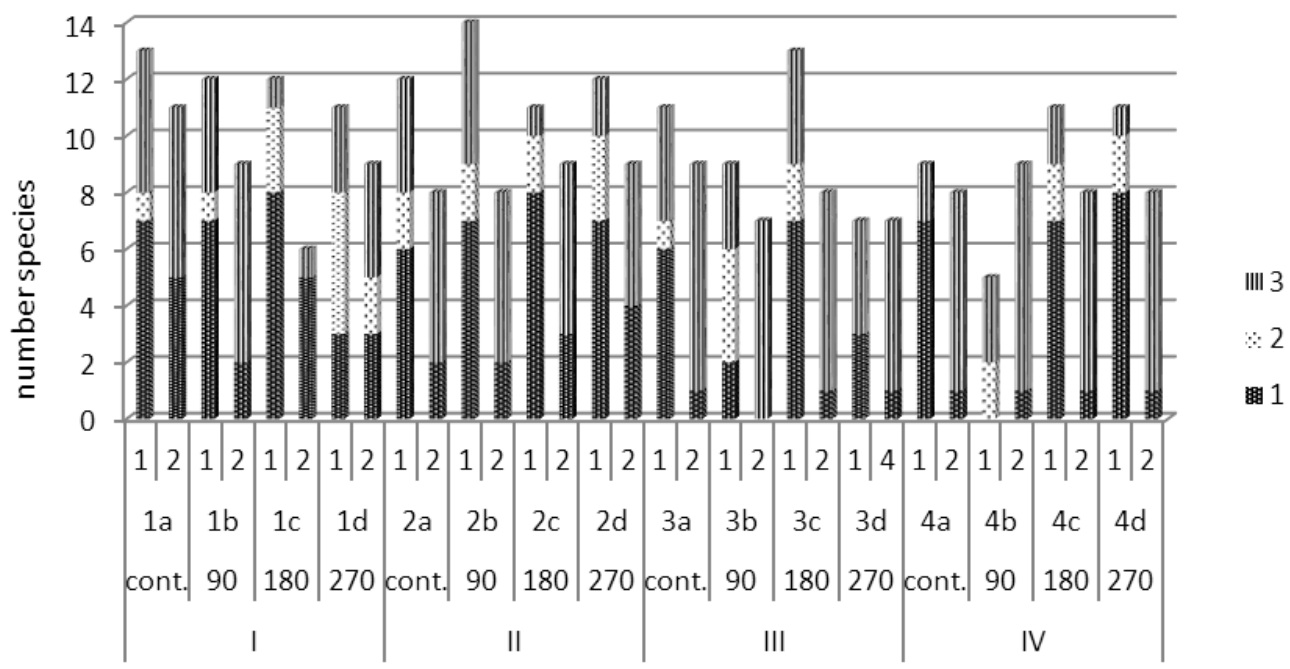

Fig. 3. The share of the species with the highest coverage: 1 - Festuca rubra, 2 - Dactylis glomerata, 3 -Calamagrostis epigejos) in the sward of reclaimed land. 1-2011,2 - 2012, 90, 180, 270 -dry weight dose of compost in $\mathrm{t} / \mathrm{ha}, 1 \mathrm{a}-4 \mathrm{a}$ control plots (no additions), $1 \mathrm{~b}-4 \mathrm{~b}$ plots with compost dose of $90 \mathrm{t} / \mathrm{ha}, 1 \mathrm{c}-4 \mathrm{c}$ plots with compost dose of $180 \mathrm{t} / \mathrm{ha}, 1 \mathrm{~d}-4 \mathrm{~d}$ plots with compost dose of $270 \mathrm{t} / \mathrm{ha}$,

I - compost: sewage sludge $100 \%$, II - compost: sewage sludge and ash $20 \%$,

III - compost: sewage sludge and ash $30 \%$, IV - compost: sewage sludge and sawdust $30 \%$

The results indicate that among recorded species, the largest coverage was achieved by the following grasses: Calamagrostis epigejos, Festuca rubra, and Dactylis glomerata (Fig. 3). Phragmites australis and Epilobium parviflorum, as well as Solidago canadensis (20-30\% cover on some patches) were distinguished by the higher frequency, yet lower density.

Fertility of habitats was assessed on the basis of the trophy indicator (Tr) (to assess the ecological indicator values of Zarzycki [13] were used. Analysis of this parameter (Fig. 4) shows the occurrence of species with 3-5 index value, i.e. moderately poor to very rich, in the examined vascular flora. Species that are the indicators of moderately poor habitats dominated (indicator 3 ). There are also species of rich and very rich habitats (indicator 4 and 5), especially in the control soil and soil reclaimed with sewage 
sludge compost. Only in the plot, where the highest dose of sewage sludge compost with $30 \%$ addition of ash was used, the exclusive presence of species that are indicators of moderately poor habitat was recorded.

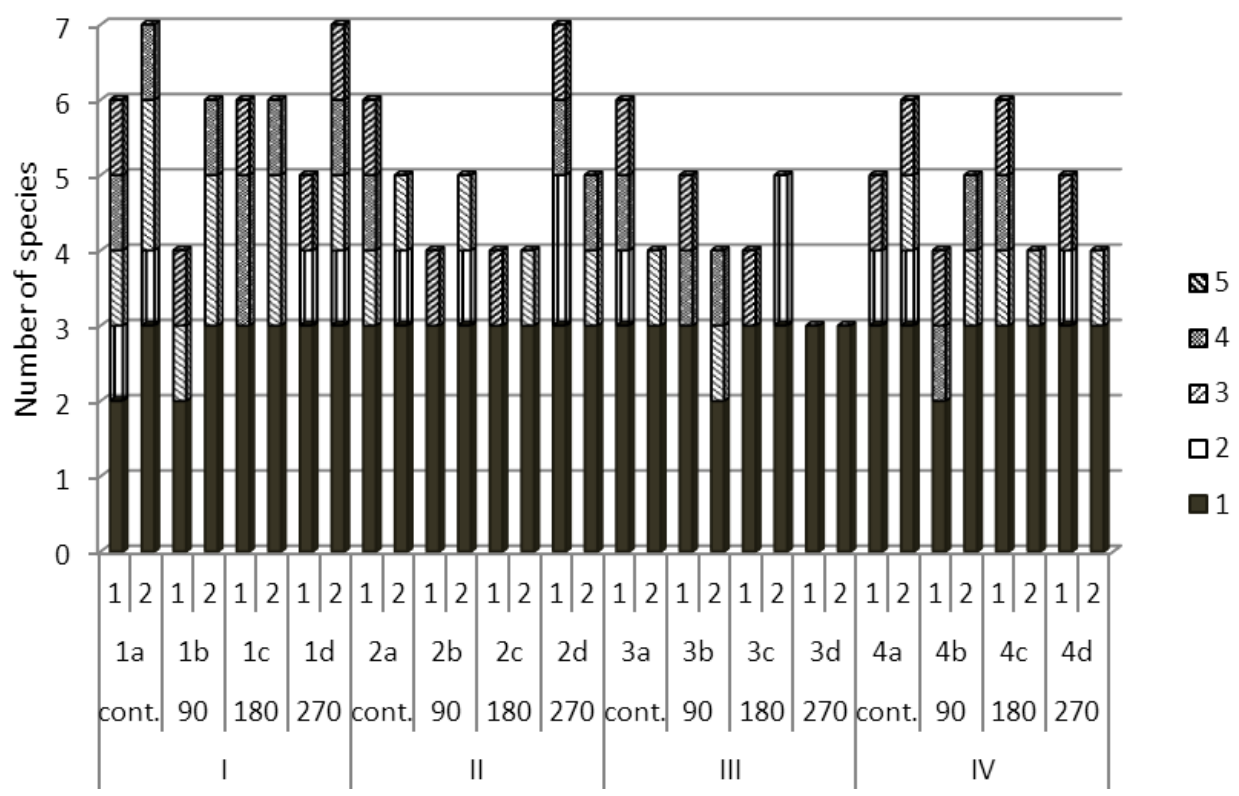

Fig. 4. Trophy value of reclamation soil: 1 - indicator 3, 2-indicator 3-4, 3-indicator 4-3, 4-indicator 4, 5 - indicator 4-5, 1-2011,2 - 2012, 90, 180, 270 - dry weight dose of compost in t/ha, 1a-4a control plots (no additions), $1 \mathrm{~b}-4 \mathrm{~b}$ plots with compost dose of $90 \mathrm{t} / \mathrm{ha}, 1 \mathrm{c}-4 \mathrm{c}$ plots with compost dose of $180 \mathrm{t} / \mathrm{ha}$, 1d-4d plots with compost dose of $270 \mathrm{t} / \mathrm{ha}$, I - compost: sewage sludge $100 \%$, II - compost: sewage sludge and ash $20 \%$, III - compost: sewage sludge and ash $30 \%$, IV - compost: sewage sludge and sawdust $30 \%$

The tested habitats were heterogeneous in nature, and the range of the humidity indicator values ranged from 2 (dry habitat) to 5-6 (wet and aquatic habitats) (Fig. 5). Species of fresh (indicator 3) and intermediate habitat between dry and fresh (indicator $2-3$ ) vs. fresh and moist ones (indicator 3-4) prevailed on the reclaimed soils. Wet and water habitat species (indicators 5 and 5-6), as well as those showing no particular humidity indicator (indicator 2-4) were present as well. As compared to 2011, the number of species in wet and intermediate (between wet and aqueous) habitats increased. The smallest number of species characteristic of such habitats was recorded in the soil reclaimed using sewage sludge compost with $30 \%$ addition of ash from power plants. At the same time, there were also species of dry habitats.

The study revealed that species growing in neutral habitats (indicator 4 and 4-5) were dominant on the reclaimed soil treated with sewage sludge compost, as well as sewage sludge with the addition of ash from the power plant or sawdust (Fig. 6). 


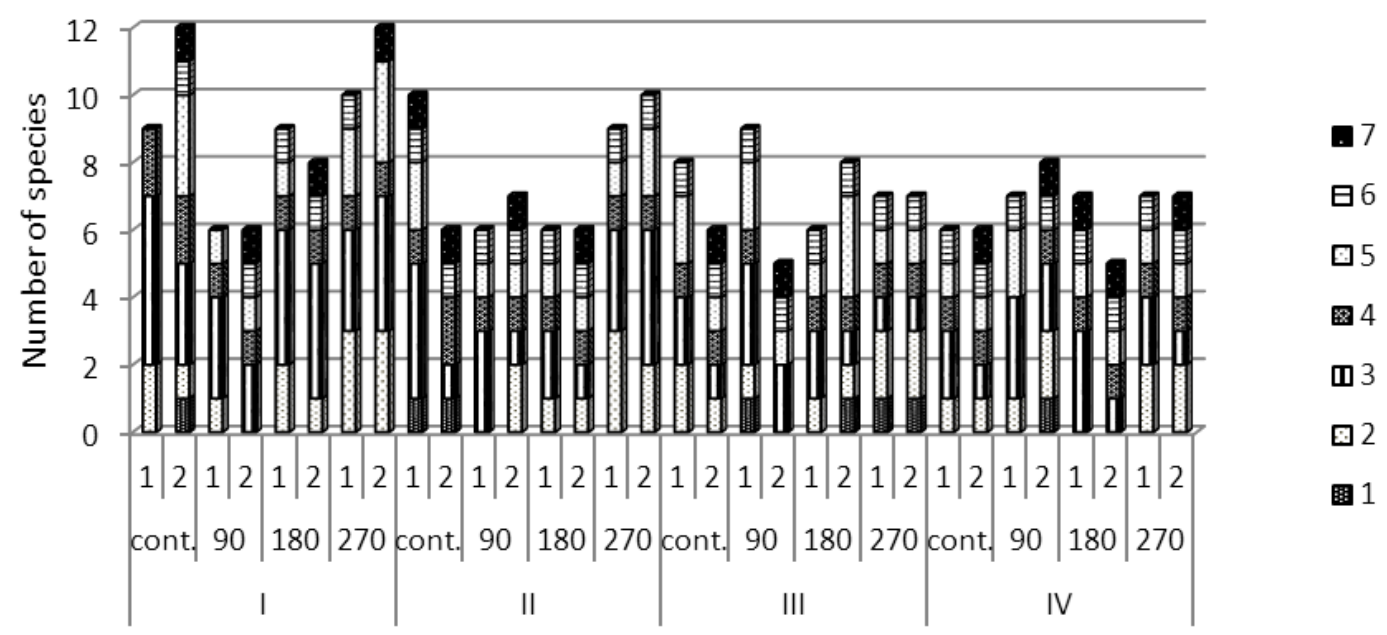

Fig. 5. Soil moisture value of reclaimed soil: 1 - indicator 2, 2 - indicator 2-3, 3 - indicator 3 , 4 - indicator 2-4, 5 - indicator 3-4, 6-indicator 5, 7 - indicator 5-6, 1-2011, 2-2012, 90, 180, 270

- dry weight dose of compost in $\mathrm{t} / \mathrm{ha}, 1 \mathrm{a}-4 \mathrm{a}$ control plots (no additions), $1 \mathrm{~b}-4 \mathrm{~b}$ plots with compost dose of $90 \mathrm{t} / \mathrm{ha}, 1 \mathrm{c}-4 \mathrm{c}$ plots with compost dose of $180 \mathrm{t} / \mathrm{ha}, 1 \mathrm{~d}-4 \mathrm{~d}$ plots with compost dose of $270 \mathrm{t} / \mathrm{ha}$, I - compost: sewage sludge $100 \%$, II - compost: sewage sludge and ash $20 \%$, III - compost: sewage sludge and ash $30 \%$, IV - compost: sewage sludge and sawdust $30 \%$

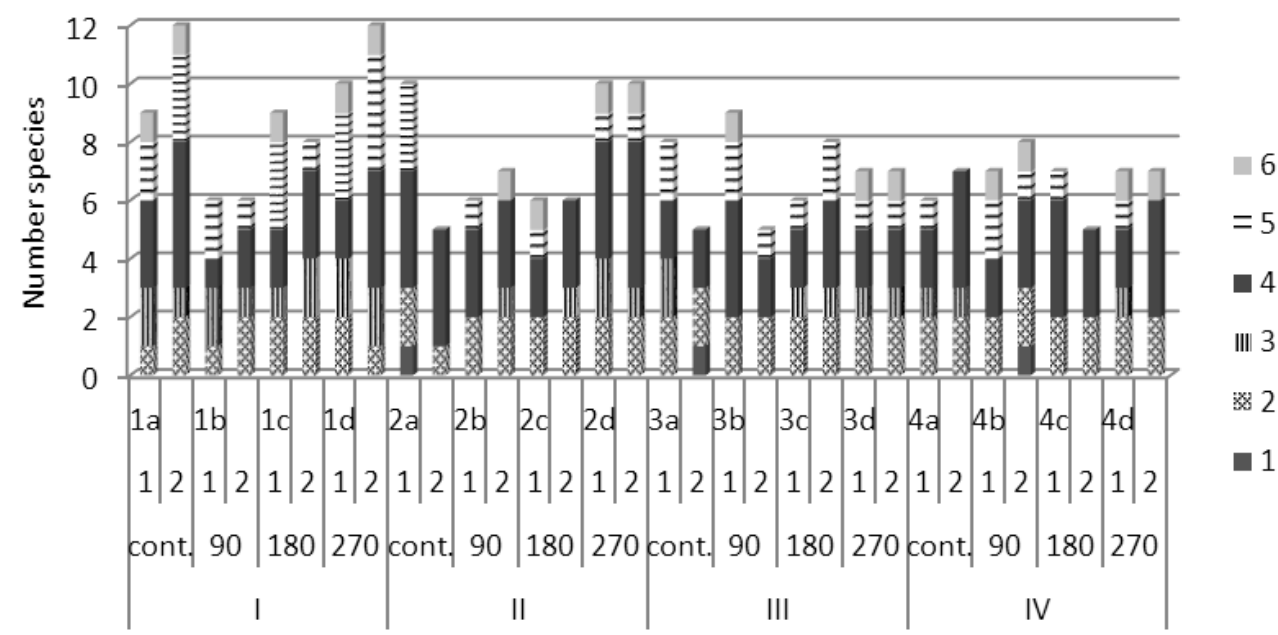

Fig. 6. Soil acidity $(\mathrm{pH})$ value of reclaimed soil: 1 - indicator $2-3,2$ - indicator 3, 3 - indicator 3-4, 4 - indicator 4, 5 - indicator 4-5, 6 - indicator 3-6, 1-2011, 2-2012, 90, 180, 270

- dry weight dose of compost in $\mathrm{t} / \mathrm{ha}, 1 \mathrm{a}-4 \mathrm{a}$ control plots (no additions), $1 \mathrm{~b}-4 \mathrm{~b}$ plots with compost dose of $90 \mathrm{t} / \mathrm{ha}, 1 \mathrm{c}-4 \mathrm{c}$ plots with compost dose of $180 \mathrm{t} / \mathrm{ha}, 1 \mathrm{~d}-4 \mathrm{~d}$ plots with compost dose of $270 \mathrm{t} / \mathrm{ha}$, I - compost: sewage sludge $100 \%$, II - compost: sewage sludge and ash $20 \%$, III - compost: sewage sludge and ash $30 \%$, IV - compost: sewage sludge and sawdust $30 \%$ 
There were fewer species occurring in acidic (indicator 2-3) and moderately acidic subsoil (indicator 3). Species with a broad spectrum in relation to the substrate acidity were also present (species with indicators in the range of 3-6).

The research performed on the soil reclaimed with composts, indicates a significantly higher number of species associated with mineral-humic soils (indicator 2), (Fig. 7). The permanent presence of Calamagrostis epigejos - species occurring on humus-poor soils (indicator 1) is also prominent. In all the analyzed patches of vegetation, the share of species (Festuca rubra, Epilobium palviflorum, Plantago lanceolata) from habitats abundant in organic matter (indicator 3) was recorded. Some patches also contain species with a broader spectrum of requirements for organic matter content (indicators $1-2$ and $2-3$ ).

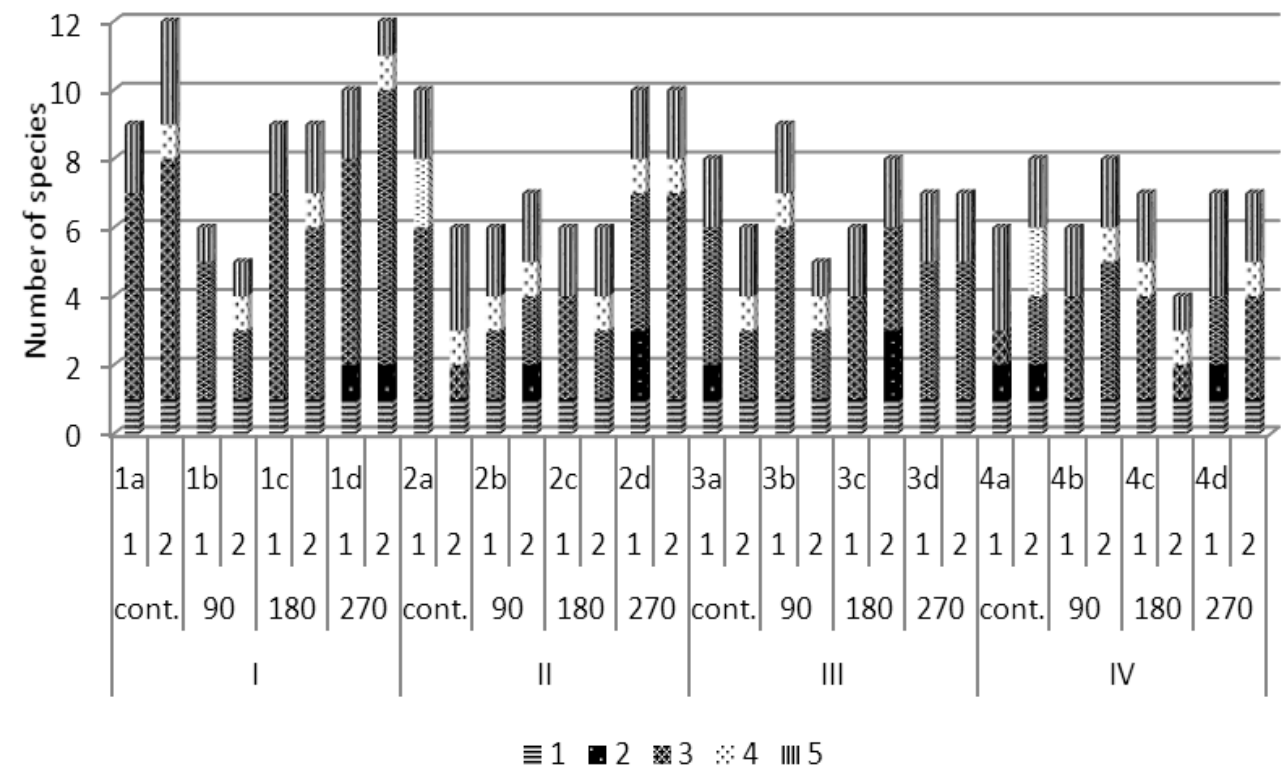

Fig. 7. Indicator of organic matter content in reclaimed soil: 1 - indicator 1,2 - indicator 1-2, 3 - indicator 2, 4-indicator 2-3, 5- indicator 3, 1-2011, 2-2012, 90, 180, 270

- dry weight dose of compost in t/ha, 1a-4a control plots (no additions), 1b-4b plots with compost dose of $90 \mathrm{t} / \mathrm{ha}, 1 \mathrm{c}-4 \mathrm{c}$ plots with compost dose of $180 \mathrm{t} / \mathrm{ha}, 1 \mathrm{~d}-4 \mathrm{~d}$ plots with compost dose of $270 \mathrm{t} / \mathrm{ha}$, I - compost: sewage sludge $100 \%$, II - compost: sewage sludge and ash $20 \%$, III - compost: sewage sludge and ash $30 \%$, IV - compost: sewage sludge and sawdust $30 \%$

The research indicates the presence of species tolerant to increased content of $\mathrm{NaCl}$ in the soil (facultative halophyte) in all reclamation variants (Table 2). The highest number of such species (5 species in 2011 and four species in 2012) was recorded in plots reclaimed using compost with $6 \%$ addition of sewage sludge. No species requiring an increased $\mathrm{NaCl}$ content (obligatory halophyte) was found. 
Indicator of plant resistance to $\mathrm{NaCl}$ content.

Number of species tolerating increased $\mathrm{NaCl}$ content (index 1) on reclaimed soil

\begin{tabular}{|c|c|c|c|c|c|c|c|c|c|c|c|c|c|c|c|c|c|}
\hline \multirow{4}{*}{ Parameter } & \multirow{2}{*}{\multicolumn{4}{|c|}{$\begin{array}{c}\text { Compost: sewage } \\
\text { sludge } 100 \%\end{array}$}} & \multicolumn{13}{|c|}{ Compost: sewage sludge } \\
\hline & & & & & \multicolumn{4}{|c|}{$+\operatorname{ash} 20 \%$} & \multicolumn{5}{|c|}{$+\operatorname{ash} 30 \%$} & \multicolumn{4}{|c|}{+ sawdust $30 \%$} \\
\hline & \multirow{2}{*}{$\begin{array}{c}\text { Con- } \\
\text { trol } \\
\end{array}$} & 90 & 180 & 270 & \multirow{2}{*}{$\begin{array}{c}\text { Con- } \\
\text { trol } \\
\end{array}$} & 90 & 180 & 270 & \multirow{2}{*}{\multicolumn{2}{|c|}{$\begin{array}{l}\text { Con- } \\
\text { trol } \\
\end{array}$}} & 90 & 180 & 270 & \multirow{2}{*}{\begin{tabular}{|c|} 
Con- \\
trol \\
\end{tabular}} & 90 & 180 & 270 \\
\hline & & & $\mathrm{t} / \mathrm{ha}$ & & & & $\mathrm{t} / \mathrm{ha}$ & & & & & t/ha & & & \multicolumn{3}{|c|}{ t/ha } \\
\hline Years of res & \begin{tabular}{|l|l|}
1 & 2 \\
\end{tabular} & \begin{tabular}{|l|l|}
1 & 2 \\
\end{tabular} & \begin{tabular}{|l|l|}
1 & 2 \\
\end{tabular} & \begin{tabular}{l|l}
1 & 2 \\
\end{tabular} & \begin{tabular}{|l|l|}
1 & 2 \\
\end{tabular} & \begin{tabular}{|l|l|}
1 & 2 \\
\end{tabular} & \begin{tabular}{l|l|}
1 & 2 \\
\end{tabular} & \begin{tabular}{l|l}
1 & 2 \\
\end{tabular} & & \begin{tabular}{l|l}
2 & 1 \\
\end{tabular} & $1 \mid 2$ & \begin{tabular}{l|l}
1 & 2 \\
\end{tabular} & \begin{tabular}{l|l}
1 & 2 \\
\end{tabular} & \begin{tabular}{|l|l|}
1 & 2 \\
\end{tabular} & \begin{tabular}{|l|l|}
1 & 2 \\
\end{tabular} & \begin{tabular}{|l|l|}
1 & 2 \\
\end{tabular} & 12 \\
\hline Number of plots & $1 \mathrm{a}$ & $1 \mathrm{~b}$ & $1 \mathrm{c}$ & $1 \mathrm{~d}$ & $2 \mathrm{a}$ & $2 \mathrm{~b}$ & $2 \mathrm{c}$ & $2 \mathrm{~d}$ & $3 a$ & $\mathrm{a}$ & $3 \mathrm{~b}$ & $3 \mathrm{c}$ & $3 d$ & $4 \mathrm{a}$ & $4 \mathrm{~b}$ & $4 \mathrm{c}$ & $4 d$ \\
\hline Numer of species & \begin{tabular}{|l|l|}
2 & 2 \\
\end{tabular} & \begin{tabular}{|l|l|}
2 & 2 \\
\end{tabular} & \begin{tabular}{|l|l|}
5 & 4 \\
\end{tabular} & \begin{tabular}{|l|l|}
3 & 3 \\
\end{tabular} & \begin{tabular}{|l|l|}
3 & 2 \\
\end{tabular} & \begin{tabular}{|l|l|}
3 & 2 \\
\end{tabular} & \begin{tabular}{|l|l|}
3 & 2 \\
\end{tabular} & \begin{tabular}{l|l|}
3 & 2 \\
\end{tabular} & 32 & \begin{tabular}{l|l}
2 & 3 \\
\end{tabular} & \begin{tabular}{|l|l|}
3 & 3 \\
\end{tabular} & \begin{tabular}{l|l}
3 & 2 \\
\end{tabular} & \begin{tabular}{|l|l|}
2 & 2 \\
\end{tabular} & \begin{tabular}{|l|l|}
3 & 2 \\
\end{tabular} & \begin{tabular}{|l|l|}
3 & 2 \\
\end{tabular} & \begin{tabular}{|l|l|}
3 & 2 \\
\end{tabular} & \begin{tabular}{|l|l|}
3 & 2 \\
\end{tabular} \\
\hline
\end{tabular}

$1-2011,2$ - 2012, 90, 180, 270 - dry weight doses of compost in t/ha, 1a-4a control plots (no additions), 1b-4b plots with compost dose of $90 \mathrm{t} / \mathrm{ha}, 1 \mathrm{c}-4 \mathrm{c}$ plots with compost dose of $180 \mathrm{t} / \mathrm{ha}$, $1 \mathrm{~d}-4 \mathrm{~d}$ plots with compost dose of $270 \mathrm{t} / \mathrm{ha}$.

Table 3

Indicator of heavy metals.

Number of species tolerating increased content of heavy metals (index 1) in reclaimed soil

\begin{tabular}{|c|c|c|c|c|c|c|c|c|c|c|c|c|c|c|c|c|c|c|c|}
\hline & \multirow{2}{*}{\multicolumn{8}{|c|}{ Compost: sewage sludge $100 \%$}} & \multicolumn{11}{|c|}{ Compost: sewage sludge } \\
\hline & & & & & & & & & \multicolumn{3}{|c|}{$+\operatorname{ash} 20 \%$} & \multicolumn{4}{|c|}{$+\operatorname{ash} 30 \%$} & \multicolumn{4}{|c|}{ + sawdust $30 \%$} \\
\hline & \multirow{2}{*}{\multicolumn{2}{|c|}{$\begin{array}{l}\text { Con- } \\
\text { trol }\end{array}$}} & 9 & & 18 & & 27 & & \multirow{2}{*}{$\begin{array}{c}\text { Con- } \\
\text { trol }\end{array}$} & \begin{tabular}{|l|l|}
90 & 180
\end{tabular} & 270 & \multirow{2}{*}{$\begin{array}{c}\text { Con- } \\
\text { trol }\end{array}$} & 90 & 180 & 270 & \multirow{2}{*}{$\begin{array}{c}\text { Con- } \\
\text { trol }\end{array}$} & 90 & 180 & 270 \\
\hline & & & & & $t / 1$ & & & & & $\mathrm{t} / \mathrm{h}$ & & & & tha & & & & tha & \\
\hline Years of research & 1 & 2 & 1 & 2 & 1 & 2 & \begin{tabular}{l|l}
1 & \\
\end{tabular} & 2 & \begin{tabular}{l|l}
1 & 2 \\
\end{tabular} & \begin{tabular}{l|l|l|l|l|}
1 & 2 & 1 & 2 \\
\end{tabular} & \begin{tabular}{l|l|l}
1 & 2 \\
\end{tabular} & \begin{tabular}{|l|l|}
1 & 2 \\
\end{tabular} & $1|2|$ & \begin{tabular}{|l|l|l|}
1 & 2 \\
\end{tabular} & \begin{tabular}{|l|l|}
1 & 2 \\
\end{tabular} & \begin{tabular}{|l|l|}
1 & 2 \\
\end{tabular} & 112 & \begin{tabular}{|l|l|l|}
1 & 2 \\
\end{tabular} & \begin{tabular}{|l|l|l|l|}
1 & 2 \\
\end{tabular} \\
\hline Number of plots & & & & & & 2 & $1 \mathrm{~d}$ & & $2 \mathrm{a}$ & \begin{tabular}{|l|l|}
$2 b$ & $2 c$ \\
\end{tabular} & $2 d$ & $3 a$ & $3 b$ & $3 \mathrm{c}$ & $3 d$ & $4 \mathrm{a}$ & $4 \mathrm{~b}$ & $4 \mathrm{c}$ & $4 d$ \\
\hline Numer of species & 1 & 2 & 1 & 1 & 1 & 1 & \begin{tabular}{l|l}
1 & \\
\end{tabular} & 1 & \begin{tabular}{l|l}
1 & 1 \\
\end{tabular} & \begin{tabular}{|l|l|l|l}
1 & 1 & 1 & 1 \\
\end{tabular} & \begin{tabular}{|l|l|} 
& 1 \\
\end{tabular} & \begin{tabular}{|l|l|}
1 & 1 \\
\end{tabular} & $2|1|$ & $1|2|$ & \begin{tabular}{|l|l|}
2 & 2 \\
\end{tabular} & \begin{tabular}{|l|l|}
1 & 1 \\
\end{tabular} & & \begin{tabular}{|l|l|}
1 & 1 \\
\end{tabular} & \begin{tabular}{|l|l|}
1 & 1 \\
\end{tabular} \\
\hline
\end{tabular}

$1-2011,2-2012,90,180,270$ - dry weight doses of compost in t/ha, 1a-4a control plots (no additions), $1 \mathrm{~b}-4 \mathrm{~b}$ plots with compost dose of $90 \mathrm{t} / \mathrm{ha}, 1 \mathrm{c}-4 \mathrm{c}$ plots with compost dose of $180 \mathrm{t} / \mathrm{ha}$, $1 \mathrm{~d}-4 \mathrm{~d}$ plots with compost dose of $270 \mathrm{t} / \mathrm{ha}$.

The study shows that in all the reclamation variants, there were species tolerating to the increased content of heavy metals in soils (Table 3). Analysis of the index of resistance to the increased content of heavy metals in soil $(M)$ [13] indicates that both in 2011 and 2012, most species tolerating the increased content of heavy metals (indicator 1) were found in plots reclaimed using the highest dose of sewage sludge compost with $30 \%$ addition of ash from power plants.

\section{DISCUSSION}

Studies performed by Skubała [14] and Dyguś et al. [15] in the former dumps, postindustrial and municipal landfills showed that Asteraceae and Poaceae were the most numerously represented families in these facilities. Klimko et al. [16] reported that 
Asteraceae, Poaceae, and Fabaceae families were the most abundant species on Wałbrzych mine dumps belonging to "Thores" and "Victoria" coal mines. Studies conducted on reclaimed pits in sulfur mine "Jeziórko" revealed that also Asteraceae, Poaceae, and Fabaceae appeared to be the most numerous species.

The analysis of syntaxonomic groups indicates the presence of meadow species from Molinio-Arrhenatheretea class and synanthropic ones from Artemisietea vulgaris, Stellarietea mediae, Epilobietea angustifolii, and Polygono-Chenopodietea classes. Unlike in other literature references $[14,15]$, no species of thermophilic meadows from Festuco-Brometea class were recorded. Considering other species, the constant share of Phragmites australis of Phragmitetea class in 2012 is noteworthy. The species appeared in most of the plots during the flood over the area.

The research has indicated that in addition to sown species included in a reclamation mixture, some species appeared spontaneously on the plots. Among the sown grass species, Lolium multiflorum and Lolium perenne were absent during the field works. Calamagrostis epigejos occurred throughout the entire object of research. This species significantly changes habitat conditions: causing dryness, hindering the air access, lowering the abundance. Calamagrostis epigejos eliminated many other plant species from the communities which were present earlier. Allelopathic properties of this species probably contribute to this phenomenon as well. Communities with its large share are greatly simplified in terms of species composition.

The analysis of the trophism index indicates the presence of species with different habitat requirements within the vascular flora of the studied habitats. There are species with low nutritional requirements, those characteristic of moderately poor and abundant habitats, as well as very abundant ones. The dominant group in the flora of the soil reclaimed using sewage sludge compost with addition of ash from power plants or sawdust are species that are indicators of moderately poor habitats (mesotrophic). Studies performed by other authors in post-industrial landfills and dumps [17-19] reveal that species preferring conditions typical of abundant soils were the most frequent group of plants. Mesophilic species were the most numerous flora group on post-mining areas of four former coal mines, while eutrophic and oligotrophic species were the smallest group. The studies performed by Dyguś et al. [15] indicate that flora of industrial dumps and ash landfills was characterized by the presence of plant species with diverse nutritional requirements. The same situation was in Wałbrzych dumps belonging to the mine "Thores" and "Victoria", sometimes differing uprising [16]. Analysis of trophy indicator pointed to the presence in these habitats, the species of vascular flora of the full spectrum of requirements trophic levels. These objects were covered both with species with very low nutritional requirements, habitat moderately poor, the rich and very fertile and the percentage of taxa was similar.

The examined habitats were covered by plant species with different moisture requirements (from dry to wet). The species preferring moist conditions typical of the fresh soils were dominant (indicator 3). Klimko et al. [16] reported that species of wet 
habitats (indicator 5) had the largest share of the flora occurring in Wałbrzych dumps. Research carried out by Dyguś et al. [15] indicates that a large number of species of moist and wet habitats was present on ash landfills, which could be explained by very high water capacity of the combustion wastes. Analysis of the organic matter content index indicates that species preferring typical mineral-organic soils dominated over the examined area. The study shows that in terms of the acidity index, species characteristic of neutral soils composed the largest group. A similar dependence according to studies conducted by Dyguś et al. [15] objects carried on 4 municipal and industrial waste. In these tests, the plants were characteristic storage medium $\mathrm{pH}$. Most species in landfills was pointers neutral.

The study suggests the occurrence of species tolerant to the increased $\mathrm{NaCl}$ content in the soil (optional halophytes) and heavy metals in examined object. However, no species requiring increased $\mathrm{NaCl}$ content (obligatory halophytes) and heavy metals were found. The research carried out by Dyguś et al. [15] indicated similar dependences. More than $18 \%$ of vascular plant species of vegetation cover, on 4 municipal waste landfills and industrial, showed resistance to salinity ground. Most are optional halophytes: Elymus repens, Calomagrostis epigejos, Cichorium intybus, Melandrium album. Only 4 species of plants were mandatory halophytes (Atriplex prostrata, Carex distans, Festuca arundinacea, Puccinelia distans). There were no facilities on these plants requiring increased content of heavy metals.

\section{CONCLUSIONS}

Occurrence of 27 species from 9 families was recorded on the soil reclaimed using sewage sludge composts with addition of diverse quantities of ash from power plants or sawdust.

- Asteraceae (10 species) and Poaceae (5 species) families were the most numerous.

- Synanthropic species that belonged to Artemisietea vulgaris, Epilobietea angustifolii, and Polygono-Chenopodietea classes, as well as meadow species from Molinio-Arrhenatheretea class were represented most numerously.

- Plots to which sewage sludge compost was applied were characterized by the largest number of species, whereas the smallest number occurred in plots reclaimed with sewage sludge compost with sawdust addition.

- The following species constituted the greatest share: Festuca rubra, Calamagrostis epigejos, and Epilobium parviflorum.

- With respect to the habitat conditions, species preferring the habitats typical of fresh soils, the subsoil trophism corresponding to the abundant soils (eutrophic), neutral soil reaction, and organic matter content similar to mineral-humus soils, prevailed.

- The most favorable habitat conditions were found on plots reclaimed with compost made of sewage sludge. 


\section{ACKNOWLEDGEMENTS}

This work was financed from the budget for science in 2010-2013 as a project No. N304 400139 .

\section{REFERENCES}

[1] Poore M.E.D., The use of phytosociological methods in ecological investigations. I. The Braun-Blanquet System, J. Ecol., 1955, 43, 1, 226.

[2] Hamzaoglu E., Duran A., A phytosociological research on the degraded forest vegetation of Dinek Mountain (Kirikkale), Gazi Univ. J. Sci., 2004, 18, 1.

[3] VAN DER MAAREL E., Transformation of cover-abundance values in phytosociology and its effects on community similarity, Vegetation, 1979, 39, 97.

[4] Thomas G.W., Exchangeable cations, [in:] A.L. Page, R.H. Miller, D.R. Keeney, Methods of Soil Analysis. Part 2. Chemical and Microbiological Properties - Agronomy Monograph, 9, 2nd Ed., Madison, Wisconsin, 1982, 159.

[5] Weber H.E., Moravec J., Theurillat J.P., International code of phytosociological nomenclature, J. Veget. Sci., 2000, 11, 739.

[6] Saglam C., A phytosociological study of the forest, shrub, and steppe vegetation of Kizildag and environs (Isparta, Turkey), Turkish J. Botany, 2013, 37, 316.

[7] Rahmonov O., SNytKo V.A., SzCZyPeK T., PARUSEl T., Vegetation development on post-industrial territories of the Silesian Upland (Southern Poland), Geography Nat. Res., 2013, 34 (1), 96.

[8] RYDZEWSKI P., The implementation of sustainable development vs. environmental attitudes in international comparative studies, Probl. Sust. Dev., 2013, 8 (1), 125.

[9] Bloesch J., Von Hauff M., Mainzer K., Mohan S.V., Renn O., Risse V., Song Y., Takeuchi K., Wilderer P.A., Sustainable development integrated in the concept of Resilence, Probl. Sust. Dev., 2015, 10 (1), 7.

[10] Braun-Blanquet J., Pflanzensozologie, Grundzüge der Vegetationskunde, Springer, Wien 1964, 1.

[11] Matuszkiewicz W., Guide for the determination of Poland's plant communities, Wyd. Nauk. PWN, Warsaw 2011, 536 (in Polish).

[12] Mirek Z., PięKoś-Mirkowa H., Zając A., Zając M., Flowering plants and pteridophytes of Poland. A checklist, Szafer Inst. of Botany, Polish Akademy of Sciences, Cracow 2002, 442.

[13] ZarZYCKi K., TrZCiŃSKa-TACiK H., RóŻAŃSKi W., SZEląG Z., WOŁEK J., KorZENiaK U., Ecological indicator values of vascular plants of Poland, Szafer Inst. of Botany, Polish Akademy of Sciences, Cracow 2002, 7.

[14] SkubaŁa K., Vascular flora of sites contaminated with heavy metals on the example of two post-industrial spoil heaps connected with manufacturing of zinc and lead products in Upper Silesia, Arch. Environ. Prot., 2011, 37 (1), 57.

[15] Dyguś K., Siuta J., Wasiak G., Madej M., Vegetation of Municipal and Industrial Landfills. Monograph, Wyd. Naukowe Gabriel Borowski, 2012, 134 (in Polish).

[16] Klimko M., Czarna A., BaŁuKa B., Vascular flora of the post-industrial estates of the city of Watbrzych, Acta Botan. Siles., 2004, 1, 7-22 (in Polish).

[17] MichaLiK B., Environmental pollution and remediation challenges in Upper Silesia Coal Basin, Poland, Proc. 2nd Meeting of the EMRAS II Workings Group 2, Vienna, 23-25 September 2009.

[18] Krook J., Svenson N., EkLund M., Landfill mining. A critical review of two decades of research, Waste Manage., 2012, 32, 513.

[19] Kim Kwon-Rae, Owens R., Potential for enhanced phytoremediation of landfills using biosolids. A review, J. Environ. Manage., 2010, 91, 791. 